\title{
Study of the Red Rice Parboilization Process
}

\author{
Georgiana Maria Vasconcelos Martins \\ Universidade Federal de Campina Grande (UFCG), Brazil
}

Victor de Souza Pereira

Universidade Federal de Pernambuco (UFPE), Brazil

\begin{abstract}
Bruna Lorrane Rosendo Martins, Severina de Sousa, Maria Elita Martins Duarte, Mario
Eduardo Rangel Moreira Cavalcanti Mata

Universidade Federal de Campina Grande (UFCG), Brazil
\end{abstract}

Hugo Miguel Lisboa Oliveira

Universidade Federal de Campina Grande, Brazil

Received: Feb. 27, 2020 Accepted: Apr. 2, $2020 \quad$ Published: Apr. 14, 2020

doi:10.5296/jas.v8i2.16509 URL: https://doi.org/10.5296/jas.v8i2.16509

\begin{abstract}
This research aimed to obtain information on hydrated red rice at different temperatures (45, 55,65 and $75{ }^{\circ} \mathrm{C}$ ) for 7 hours. During the hydration process, the structural and morphological modifications of red rice were observed, as well as the hydration kinetics by Peleg (1988), Cavalcanti-Mata \& Duarte (2018) and Duarte \& Cavalcanti Mata (2018) models. There were performed X-ray diffraction (XRD) and scanning electron microscopy (SEM) analysis in order to identify the type of crystallinity and to obtain images referring to the surfaces of the starch granules particles. The results identified by the XRD analysis that hydrated red rice is classified as type a starch. And the SEM analysis identified that there was a change in its morphological structure, providing the beginning of red rice starch gelatinization. The absorption kinetics showed that above 5 hours of hydration at 55,65 and $75{ }^{\circ} \mathrm{C}$, the red rice grain reaches $28 \%$ water content. Mathematical modeling proves that the models proposed by Cavalcanti \& Duarte and Cavalcanti Mata \& Duarte (2018) performed better than Peleg's model (1988), according to the statistical parameters evaluated (P, SE, DQM, and $\mathrm{R}^{2}$ ). The XRD and SEM results of red rice hydrated for 7 hours at $55^{\circ} \mathrm{C}$, autoclaved for 14,22 and 30
\end{abstract}


minutes and dried at 50,60 and $70{ }^{\circ} \mathrm{C}$ confirm parboiling process since the starchy structure of red rice was very distinct from the type A starch structure and confirmed the starch gelatinization.

Keywords: red rice, hydrated, vaporization, parboiling, drying

\section{Introduction}

Given that there is growing interest in finding new sources of starch with new and unique properties (WANG et al. 2015; HUANG et al. 2015, EJEBE et al. 2015, SHAH et al. 2017, CONDÉS et al. 2018, MERCI et al. 2019) several studies were performed using X-ray diffraction analysis to distinguish the three types of crystallinity for the different starch granules. These crystallinity patterns depend in part on the length of the amylopectin chains, the packing density within the granules, as well as, the presence of water (LIMA et al. 2012; DUTTA et al. 2015, HUANG et al. 2015, CAPPA et al. 2016, PINKAEW et al. 2017). Lamberts et al. (2009) and Oli et al. $(2014,2016)$ have previously discussed that cereal starches have a type A crystallinity, tubercle starches a type B crystallinity, and root and seed starch a type $\mathrm{C}$ crystallinity. Although there is no crystallinity pattern assigned to fruit starches.

Scanning electron microscopy (SEM) analyses have been explored in recent research on different starch sources, with the aim of obtaining images referring to the surfaces of the starch granule particles (ARNS et al. 2015; CAPPA et al. 2016, LIMA et al, 2012; WANG et al. 2015; HUANG et al. 2015). Taking into account that the parboiling process is a hydrothermal treatment where paddy rice is immersed in heated water, resulting in the breakdown of hydrogen bonds between amylose and amylopectin, providing uniform and irreversible water absorption by the grain (hydration step), consequently the grain goes through the gelatinization steps (vaporization step) of the starch and drying of the grain (DUTTA, MAHANTA, 2014, OLI et al. 2014; BUGGENHOUT et al. 2013, SITTIPOD e SHI et al. 2016). Thus, each of these steps in the parboiling process has a specific goal that will result in grains with different characteristics when compared to conventional rice. After these three steps, the parboiled rice can be marketed in its entirety or be polished where the polished parboiled grain is obtained (DUTTA, MAHANTA, 2014).

The parboiling process begins with the hydration of starch granules by immersion in heated water, breaking the hydrogen bonds between amylose and amylopectin, providing uniform and irreversible water absorption by the grain, consequently producing a rice in bark with a water content around 30-32\% (BUGGENHOUT et al. 2013, BALBINOTI et al. $2016^{\mathrm{a} \text { b }}$ ). The initial water content is important in the hydration stage of parboiled rice, as it interferes in the physical integrity of the grains. If it has initial water content below $13 \%$ there will be a poor distribution of water inside, making homogeneous hydration difficult, with consequent increase of broken grains at the end of the parboiling process (HELBIG et al. 2008; DUTTA, MAHANTA, 2014). After hydration, the rice follows the starch gelatinization step, which occurs in parallel to the hydration step. During starch gelatinization, the husked rice grains are vaporized at a temperature ranging from $100-120{ }^{\circ} \mathrm{C}$ for $5-30 \mathrm{~min}$, with water content around 35\% (Buggenhout et al. 2013; Dutta, Mahanta, 2014; Oli et al. 2014). To finalize the 
parboiling process occurs the drying process, the rice grain becomes more resistant to the stresses caused during processing, increasing the yield in whole grains. This results in a naturally more nutritious product with improved physical characteristics compared to the polished and integral ones (DEMONT et al. 2012). For safe storage, the rice must be dried at water content below 14\% (BUGGENHOUT et al. 2013). According to Amato et al. (2005), Botelho et al. (2010) and Balbinoti et al. $\left(2018^{\mathrm{a}, \mathrm{b}}\right)$, the water content in the range $28-30 \%$ is indispensable for the complete gelatinization of grain endosperm starch during the hydration of rice starch. Numerous studies have been observed to identify the characteristics of various physical and chemical processes aimed at modifying starch from different sources: Rice starch acetylation (BARTZ et al. 2012 e COLUSSI et al. 2015), oat starch acetylation (SHAH et al. 2017), rice starch parboilization (DUTTA et al. 2015, SITTIPOD e SHI 2016) and pigmented rice starch parboilization (PAIVA et al. 2016).

Many studies also have been performed showing the importance of the absorption kinetics process in different food products to describe the hydration phenomenon, for example, Bambara peanuts (JIDEANI \& MPOTOKWANA, 2009), beans (OLIVEIRA et al. 2013), chickpeas (SHAFAEI et al. 2016), rice (CHEEVITSOPON \& NOOMHORM, 2011; BALBINOTI et al. 2016 ${ }^{\mathrm{a}}$ ) ), soya (QUICAZÁN et al. 2012; FRACASSO et al. 2014). In these studies, the influence of temperature on the rate and amount of water diffused into the product has been identified. Water absorption kinetics of legumes have been described by Peleg's (1988) empirical model or by analytical models derived from Fick's diffusion law (COUTINHO, 2006). Although empirical models are simple to apply and provide a reasonable description of the multi-grain hydration process (RESENDE and CORREAA, 2007; GHAFOOR et al. 2014), it is not, however, derived from any kind of physics law or diffusion theory. (PELEG, 1988).

The grain hydration process also describes a phenomenon controlled by internal diffusion. Hydration depends on time, temperature and concentration of soluble solids. The amount of water absorbed increases with increasing of temperature and hydration time (RESENDE e CORRÊA, 2007; COUTINHO et al. 2006; BALBINOTI et al. 2016 ${ }^{\mathrm{a}, \mathrm{b}}$ ).

Peleg's (1988) empirical model represents well hydration in food products. The major advantage of this model is its simplicity over other theoretical and empirical models. This model has already been satisfactorily used to describe the hydration phenomenon in Bambara peanuts (JIDEANI\&MPOTOKWANA, 2009), beans (OLIVEIRA et al. 2013), chickpeas (SHAFAEI et al. 2016); rice (CHEEVITSOPON\&NOOMHORM, 2011), soya (QUICAZÁN et al. 2012; FRACASSO et al. 2014) among others.

$$
X_{t}=X_{o}+\frac{t}{k_{1}+k_{2} t}
$$

The constants $\mathrm{k}_{1}$ and $\mathrm{k}_{2}$ of the proposed model for modeling the grain hydration process were obtained by adjusting the linearized Peleg's equation, as described in Equation 2, where $\mathrm{X}_{\mathrm{t}}$ represents the water content at a given time in $\mathrm{kg}(\mathrm{kgms})^{-1} ; \mathrm{X}_{0}$ is the initial product's water 
content in $\mathrm{kga}(\mathrm{kgms})^{-1} ; \mathrm{k}_{1}$ is the Peleg's constant rate in $(\mathrm{h} \mathrm{kgms}) \mathrm{kg}^{-1} ; \mathrm{k}_{2}$ is Peleg's constant capacity in $(\mathrm{kgms}) \mathrm{kg}^{-1}$; and $\mathrm{t}$ represents the time in hours.

$$
\frac{t}{x_{0}+x_{t}}=k_{1}+k_{2} t
$$

One of the great advantages of Peleg's model is the time gain to predict the kinetics of water absorption in food, allowing the calculation of equilibrium water content (PELEG, 1988). Equilibrium water content can be obtained by Equation 2 itself, when time tends to infinity, resulting on Equation 3, where Xe is the equilibrium water content in kga (100 kgms) ${ }^{-1}$.

$$
X_{e}=X_{\circ}+\frac{1}{k_{z}}
$$

After the hydration, gelatinization and autoclaving steps, the rice has high water content, between $30-35 \%$ on a wet basis. Thus, before storage and/or processing it should be dried until a maximum of $13 \%$ water content. Once dried, the rice will be husked, optionally polished and selected. (BUGGENHOUT et al. 2013; DUTTA, MAHANTA, 2014; OLI et al. 2014).

Several mathematical models have been used to describe the hydration process of agricultural products. Several theories have been proposed to predict the hydration and drying behavior of grains and seeds, however, semiempirical and empirical relationships have often been the best options for describing the hydration process even with their validity restricted by the experimental conditions where data were obtained (CHEEVITSOPON \&NOOMHORM, 2011; BALBINOTI et al. (2018) ${ }^{\mathrm{a}, \mathrm{b}}$ ).

Studies performed by Dutta et al (2015), Sittipod and Shi (2016), and Paiva et al. (2016), $\mathrm{X}$-ray diffractograms and scanning electron microscopy (SEM) confirm the chemical, structural and morphological changes of starch, thus confirming the parboiling process of rice.

In this context, our work aims to evaluate the hydration kinetics, to characterize hydrated red rice by X-ray diffraction (XRD) and scanning electron microscopy (SEM) and to characterize red rice under vaporization at different autoclave times and drying temperatures.

\section{Methodological Details}

This research was carried out at the Plant Physiology and Plant Pathology Laboratories, both belonging to the Academic Unit of Agronomy of the Federal University of Campina Grande (UFCG) - Campus Pombal. As well as, the Food Engineering Laboratories of the Federal University of Campina Grande (UFCG) - Campus Campina Grande. X-ray diffraction (XRD) analyzes were performed at the Nanotechnology Laboratory of the Center for Strategic Technologies of the Northeast - Cetene. Scanning Electron Microscopy (SEM) analyzes were performed at the Multifunctional Materials and Numerical Experimentation Laboratory - ECT, UFRN, at the Food Engineering Laboratory of the Federal University of Campina Grande, 
Campus Campina Grande, and at the Materials Engineering Laboratory of the Federal University of Rio Grande do Norte (UFRN).

\subsection{Raw Material}

For the trials was used the husked red rice of the traditional red variety, 2014/2015 and 2015/2016 harvest, produced in the countryside of the Paraíba State, Brazil. The sample field comprised a $10 \mathrm{~kg}$ plot for cultivation from producers located in the city of Santana dos Garrotes, Paraíba State, Brazil.

Initially, manual pre-processing of the material was done to eliminate defective grains, shells and foreign materials. Then the samples were stored in the absence of light at room temperature and stored in the necessary amount for each experiment. The average initial water content of the samples was $10 \%$ on wet basis, determined by forced oven drying at $105 \pm 1{ }^{\circ} \mathrm{C}$ for 24 hours. The initial water content was determined by the standard oven method at $105 \pm 1{ }^{\circ} \mathrm{C}$ for a period of $24 \mathrm{~h}$ using five subsamples of red rice grains of $10 \mathrm{~g}$ each, as described by the Seed Analysis Rules (BRASIL, 2009).

\subsection{Pre-drying and Washing}

At starting, $1 \mathrm{~kg}$ of red rice grains were subjected to washing to remove dirt so that it reached $25 \%$ water content on wet basis. For storage, the wet grains with water content around $25 \%$, were subjected to drying in Marqlabor oven with circulation at $50^{\circ} \mathrm{C}$ until the wet red rice grains reached the water content of $13 \%$. Then the $500 \mathrm{~g}$ dough with water content around $13 \%$ wet were vacuum packed in the Selovac ${ }^{\circledR}$ sealer.

\subsection{Red Rice Hydration}

The methodology followed in this stage was developed based on the hydration process studies of several authors (AYAMDOO et al., 2014; SHAFAEI et al. 2016 e BALBINOTI et al. $\left.(2018)^{\mathrm{a}, \mathrm{b}}\right)$. In the hydration process, $200 \mathrm{~g}$ samples of red rice were used, which were hydrated with distilled water in a ratio of two volumes of water to one of grains, at 45 to $75{ }^{\circ} \mathrm{C}$ in a water bath (Quimis ${ }^{\circledR}$ Thermostatic Bath) for a period of seven hours, with three repetitions per temperature.

During the hydration period, the samples were periodically weighed on a $0.001 \mathrm{~g}$ precision digital scale (Bel Engineering $®$ Brand). For this step, the samples were taken from the immersion and left for three minutes so that the surface water could be removed, weighed and subsequently returned to the immersion. The water content at a given time after the start of the experiment was calculated based on the mass increase of the samples in comparison with the initial mass.

\subsection{Vaporization (Autoclaving of the Red Rice)}

The vaporization step began shortly after hydration at $55^{\circ} \mathrm{C}$ for 7 hours. This condition was chosen by the absorption curves results and by XRD and SEM analysis of hydrated red rice at temperatures of $45{ }^{\circ} \mathrm{C}$ to $75{ }^{\circ} \mathrm{C}$ for 7 hours. The hydrated red rice at $55{ }^{\circ} \mathrm{C}$ for 7 hours was placed in a nylon sieve to eliminate water. Subsequently, the rice was subjected to a spraying 
process at $1 \mathrm{kgf} / \mathrm{cm}^{2}$ pressure and $120{ }^{\circ} \mathrm{C}$ temperature in a Prismatec ${ }^{\circledR}$ vertical autoclave. The length of stay in the vertical autoclave was analyzed at 14, 22 and 30 minutes. For each length of stay were performed three repetitions. After the vaporization process, the parboiled rice remained in the desiccator for a period of 24 hours for cooling. Then, the samples obtained for each residence time were subjected to drying in an oven with air circulation.

\subsection{Parboiled Rice Drying Process}

The red rice samples parboiled for 14, 22 and 30 minutes in an autoclave were submitted to a Marqlabor air drying oven at 50,60 and $70{ }^{\circ} \mathrm{C}$ drying temperatures. The vaporization and drying experiments were repeated 3 times for each condition of autoclave time (14, 22 and 30 minutes) and drying temperature $\left(50,60\right.$ and $\left.70{ }^{\circ} \mathrm{C}\right)$. Parboiled red rice, after 24 hours of vaporization process, was dried in a Marqlabor air circulation oven at 50, 60 and $70{ }^{\circ} \mathrm{C}$. Samples of approximately 200 grams of husked parboiled red rice were subjected to the drying process until reach $10 \%$ of water content on a wet basis.

\subsection{X-ray Diffraction (XRD) and Scanning Electron Microscopy (SEM) Analyzes}

\subsubsection{X-ray Diffraction Analysis}

The technique of X-ray diffraction through coherent X-ray scattering by organized structures (crystals) made it possible to perform morphological studies on materials, determining their crystal structure and their (percentage) crystalline fraction.

The X-ray diffractograms of the red rice samples were obtained on an X-ray diffractometer from Brucker and D8 Advance Model, operated with Cu K tube (alpha) radiation; with $40 \mathrm{kV}$ Voltage and $40 \mathrm{~mA}$ Current with Nickel Filter, sweep rate of $1 \% \mathrm{~min}$ at room temperature. The diffraction scanning range has been adjusted to angles from $5^{\circ}$ to $40^{\circ}(2 \theta)$.

Calculations of the index or degree of crystallinity of fresh rice were determined using the method used by Hulleman et al. (1999), through Equation 4, where $I_{c r}$ is the crystallinity index, $\mathrm{H}_{\mathrm{a}}$ is the height corresponding to the amorphous phase relative to the baseline and $\mathrm{H}_{\mathrm{c}}$ is the height corresponding to the crystalline peak.

$$
I_{\mathrm{cr}}=\frac{\mathrm{H}_{\mathrm{c}}}{\mathrm{H}_{\mathrm{c}}+\mathrm{H}_{\mathrm{a}}}
$$

The method established by Ruland (1974) was applied which proposes the deconvolution of the diffraction peaks to determine the degree of crystallinity. The areas indicated in the curve were applied to equation (5) established by Dutta et al (2015).

$$
\% \text { Crystallinity }=\frac{\sum \text { areas below the curves subjected to deconvolutions }}{\text { Total area }}(5)
$$




\section{Macrothink}

\subsubsection{Scanning Electron Microscopy Analysis (SEM)}

Images of samples of red rice grains, fresh rice, pre-dried rice and hydrated rice (in the temperature range $45{ }^{\circ} \mathrm{C}$ to $75^{\circ} \mathrm{C}$ ) were obtained by scanning electron microscopy with increases of $200 \mathrm{x}$, scanning electron microscope model Hitachi Table top Microscope TM-3000, with accelerating voltage of $5 \mathrm{kV}, 15 \mathrm{kV}$ Hitachi. One grain of each husked sample was placed on a carbon tape and observed under a microscope.

The images of parboiled husked red rice grains with autoclave residence time 14, 22 and 30 minutes and drying temperatures of 50,60 and $70{ }^{\circ} \mathrm{C}$ were also obtained by scanning electron microscopy with $1 \mathrm{kx}$ magnifications, performed on a Tescan Vega 3 scanning electron microscope, operated at $10 \mathrm{kV}$, with $1000 \mathrm{x}$ magnifications.

\subsection{Statistical Analysis of the Hydration Stage of Red Rice}

The criterion for the analysis of the mathematical modeling of the red rice hydration step was the determination coefficient $\left(\mathrm{R}^{2}\right)$, the mean square deviation (DQM), the estimate of the deviation (SE) and the relative mean error $(\mathrm{P})$, represented by Equations 6 to 8, respectively.

$$
\begin{gathered}
D Q M=\sqrt{\frac{\sum_{i=1}^{N}\left(R X_{\text {exp }}-R X p r e d\right)^{2}}{N}} \\
S E=\sqrt{\frac{\sum_{i=1}^{N}\left(R X_{\text {exp }}-R X p r e d\right)^{2}}{G L R}} \\
P=\frac{100}{N} \cdot \frac{\sum_{i=1}^{N}\left|R X_{\exp }-R X p r e d\right|}{R X_{\text {exp }}}
\end{gathered}
$$

where,

$R^{2}$ - Determination coefficient, $\%$

$S E$ - Estimate of the deviation

$P$ - Relative mean error, $\%$

$N$ - Number of data observed

Z- number of model's parameters

$D Q M$ - Mean square deviation 
$R X_{\exp }$ - Experimental water content ratio

$R X_{\text {pred }}$ - Water content ratio predicted by the model

$G L R=N-z-$ Degrees of freedom of the model (number of observed data minus the number of model parameters).

\section{Results and Discussion}

\subsection{Structural Evaluation by X-ray Diffraction}

Figure 1 shows the $\mathrm{x}$-ray diffractograms corresponding to the samples of fresh red rice (e), pre-dried red rice at $50{ }^{\circ} \mathrm{C}(\mathrm{f})$, hydrated red rice at $45^{\circ} \mathrm{C}(\mathrm{g})$, hydrated red rice at $55^{\circ} \mathrm{C}(\mathrm{h})$, hydrated red rice at $65{ }^{\circ} \mathrm{C}(\mathrm{i})$, hydrated red rice at $75^{\circ} \mathrm{C}(\mathrm{j})$, respectively.

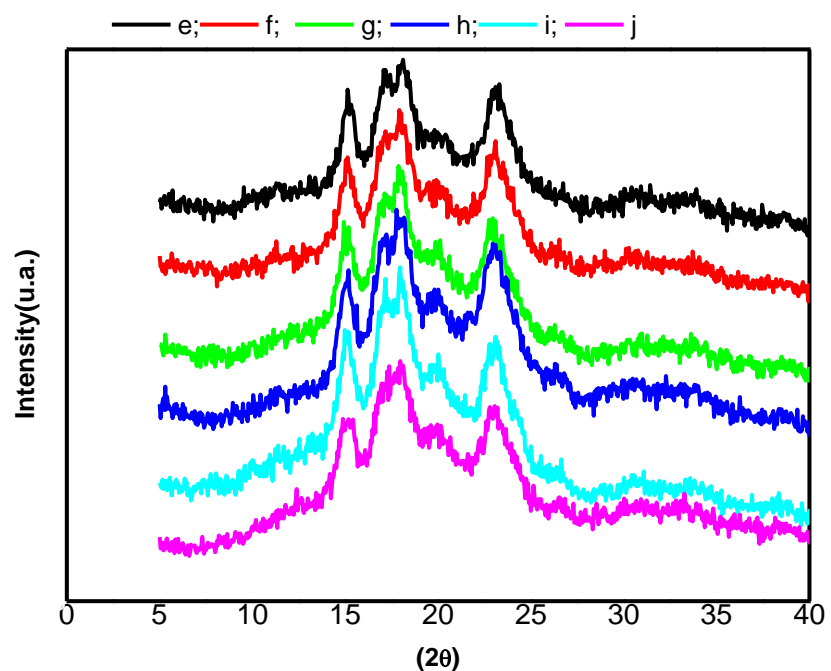

Figure 1. X-ray diffractograms of fresh red rice (e), red rice dried at $50{ }^{\circ} \mathrm{C}(\mathrm{f})$, red rice hydrated at $45{ }^{\circ} \mathrm{C}$ for 7 hours (g), red rice hydrated at $55{ }^{\circ} \mathrm{C}$ for 7 hours (h); hydrated red rice at $65{ }^{\circ} \mathrm{C}$ for 7 hours (i); hydrated red rice at $75^{\circ} \mathrm{C}$ for 7 hours (j)

The results observed in Table 1 show the intensity peaks at $2 \theta$ diffraction angles at approximately $15^{\circ} ; 17^{\circ} ; 18^{\circ}$ and $23^{\circ}$, confirming that they agree with the data reported by Cappa et al. (2016) and Dutta et al. (2015), who state that cereal starches with crystallinity type A have specific diffraction angles of $2 \theta$ at approximately $15^{\circ} ; 17^{\circ} ; 18^{\circ}$ and $23^{\circ}$. With these results it can be observed that the hydration of red rice at temperatures from $45{ }^{\circ} \mathrm{C}$ to $75^{\circ} \mathrm{C}$ does not cause changes in the amylaceous structure of hydrated red rice, so the starch continues with characteristic of the cereal starches type A. 


\section{Macrothink}

Table 1. Diffraction angles $2 \theta$ for red rice samples

\begin{tabular}{cc}
\hline Red rice samples & Peak angles (Degrees) \\
\hline Fresh (e) & $15.02^{\circ} ; 17.13^{\circ} ; 18.12^{\circ} ; 23.22^{\circ}$ \\
Pre-dried at $50{ }^{\circ} \mathrm{C}(\mathrm{f})$ & $15.04^{\circ} ; 17.20^{\circ} ; 17.97^{\circ} ; 23.04^{\circ}$ \\
Hydrated at $45^{\circ} \mathrm{C}(\mathrm{g})$ & $15.15^{\circ} ; 17.27^{\circ} ; 17.92^{\circ} ; 22.83^{\circ}$ \\
Hydrated at $55^{\circ} \mathrm{C}(\mathrm{h})$ & $15.32^{\circ} ; 17.03^{\circ} ; 18.02^{\circ} ; 22.93^{\circ}$ \\
Hydrated at $65^{\circ} \mathrm{C}(\mathrm{i})$ & $15.25^{\circ} ; 17.10^{\circ} ; 17.97^{\circ} ; 23.16^{\circ}$ \\
Hydrated at $75^{\circ} \mathrm{C}(\mathrm{j})$ & $15.15^{\circ} ; 16.99^{\circ} ; 18.07^{\circ} ; 22.83^{\circ}$ \\
\hline
\end{tabular}

Table 2 shows calculated crystallinity values for fresh red rice (sample e), pre-dried at $50{ }^{\circ} \mathrm{C}$ (sample f) and hydrated at temperatures from $45^{\circ} \mathrm{C}$ to $75^{\circ} \mathrm{C}$ (samples $\mathrm{g}, \mathrm{h}, \mathrm{i}$ and $\mathrm{j}$ ).

Table 2. Calculated crystallinity for red rice

\begin{tabular}{cc}
\hline Red Rice Sample & Crystallinity (\%) \\
\hline Fresh (e) & 65.61 \\
Pre-dried at $50{ }^{\circ} \mathrm{C}$ (f) & 61.22 \\
Pre-dried at $50{ }^{\circ} \mathrm{C}$ and Hydrated at $45{ }^{\circ} \mathrm{C}$ (g) & 61.11 \\
Pre-dried at $50{ }^{\circ} \mathrm{C}$ and Hydrated at $55^{\circ} \mathrm{C}(\mathrm{h})$ & 60.68 \\
Pre-dried at $50{ }^{\circ} \mathrm{C}$ and Hydrated at $65^{\circ} \mathrm{C}(\mathrm{i})$ & 57.17 \\
Pre-dried at $50{ }^{\circ} \mathrm{C}$ and Hydrated at $75{ }^{\circ} \mathrm{C}(\mathrm{j})$ & 54.21 \\
\hline
\end{tabular}

According to Lima \& Andrade (2010), starch crystallinity is proportional to its composition, regular starches are composed of 20 to $30 \%$ amylose and $70 \%$ to $80 \%$ amylopectin. The observed crystallinity in the present study is between 54.21 to $65.61 \%$ of amylopectin, values below the crystallinity standards for regular starches which should be between $70 \%$ and $80 \%$. Figure 2 shows the individual diffractograms with crystallinity calculations. 


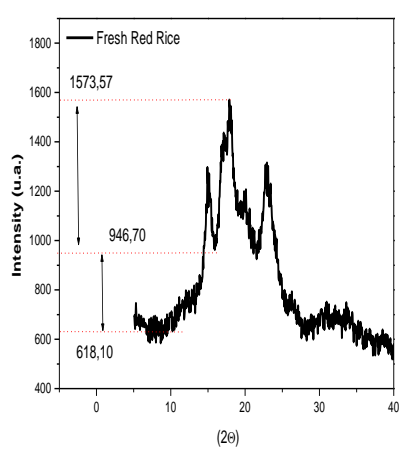

(a)

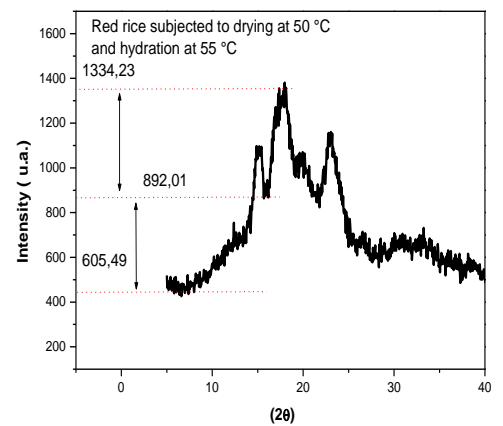

(d)

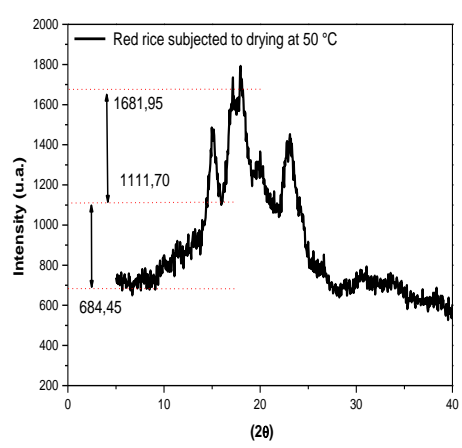

(b)

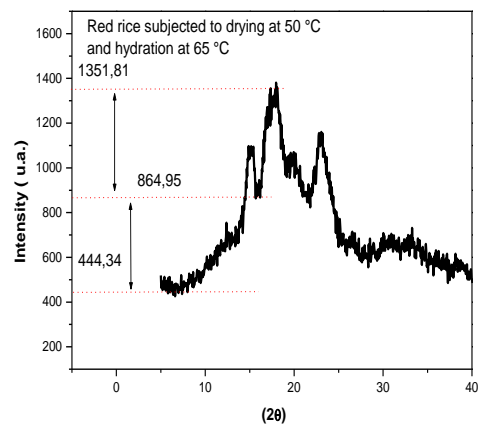

(e)

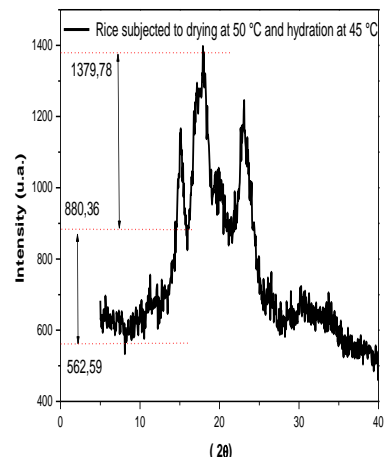

(c)

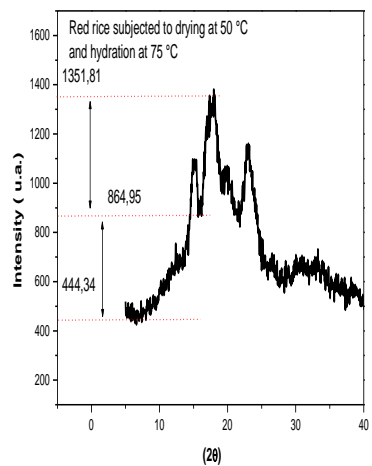

Figure 2. X-ray diffractograms of red rice: Fresh (a); Pre-drying at $50{ }^{\circ} \mathrm{C}$ (b); Pre-drying at $50{ }^{\circ} \mathrm{C}$ and hydration for 7 hours at temperatures from $45^{\circ} \mathrm{C}$ to $75^{\circ} \mathrm{C}$ (c-f)

The values of Table 2 show a reduction in crystallinity; However, there is no evidence of the occurrence of gelatinization of rice starch, as observed in the diffractograms in Figure 1, where the diffraction angles are at $15^{\circ}, 17^{\circ}, 18^{\circ}$, and $23^{\circ}$, characteristics of starch type A.

Denardin \& Silva (2008), Lamberts et al. (2009), Sittipod \& Shi (2016) state that the contact of rice with heated water contributes to the beginning of the loss of the structural organization of rice starch, it means that there is a loss of birefringence occurrence of the fusion of grain crystals. Since there was a reduction in crystallinity during the hydration process, in the temperature range of $45^{\circ}$ to $75^{\circ} \mathrm{C}$, as shown in Table 2, it may have started the gelatinization of red rice starch. During the gelatinization phase, there is a rupture of the granular structure, swelling, hydration, and solubilization of starch molecules, as reported by Singh et al. (2003), Ejebe et al. (2015) and Condés et al. (2018). Since the gelatinization process is controlled in part by the molecular structure of amylopectin (chain length, branch length, molecular 
weight), starch composition (amylose/amylopectin ratio and phosphorus content) and granular architecture (proportion of crystalline and amorphous regions). It explains why the crystallinity values between 54.21 to $65.61 \%$ of the red rice in the present study are well below the reference values of 70 to $80 \%$ of regular starches.

\subsection{Absorption Kinetics and Mathematical Modeling}

Initial water absorption values for all trials were around $15 \%$ on a dry basis. The percentage of water absorption of red rice grains during hydration is shown in Figure 2. Figure 3 also shows the mathematical modeling to Peleg's model to describe the phenomenon of water absorption at temperatures of $45^{\circ} \mathrm{C}, 55^{\circ} \mathrm{C}, 65^{\circ} \mathrm{C}$ and $75^{\circ} \mathrm{C}$.

From the water absorption data as a function of temperature and time of hydration of red rice in Figure 3, it can be seen that red rice exhibited a characteristic behavior of agricultural products submitted to the hydration process. It can be observed that throughout the hydration process it exhibits a high rate of water absorption, tending to stabilize over time as the water content of the product approaches equilibrium.

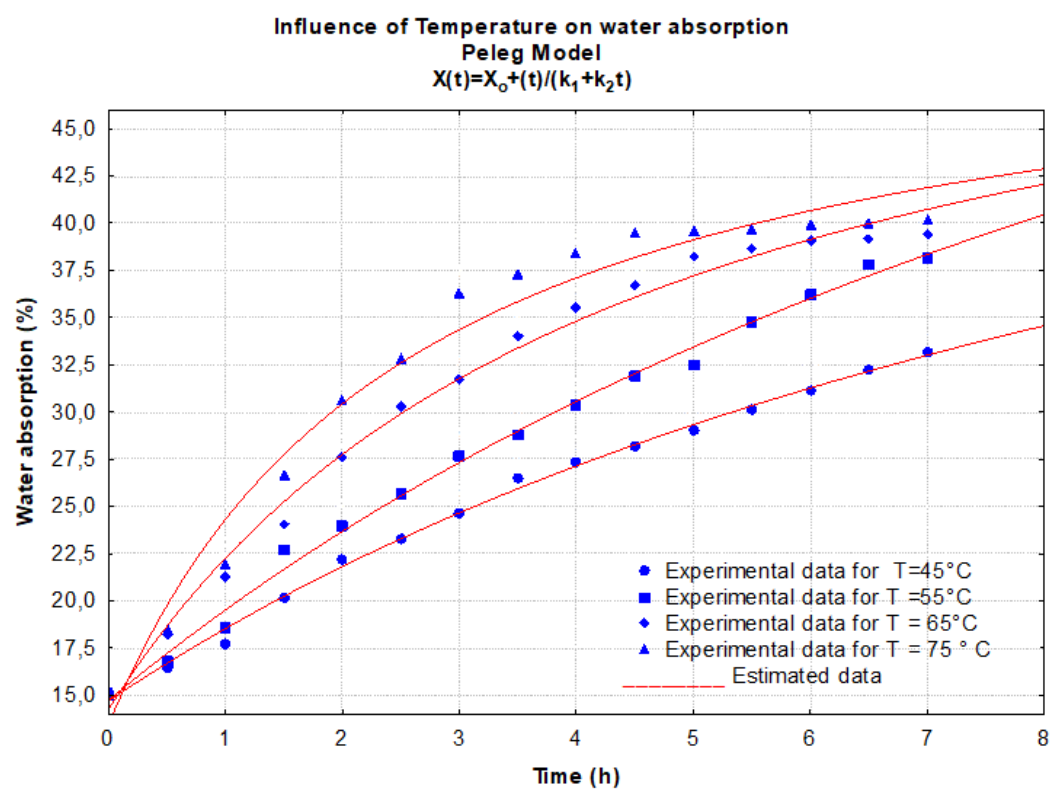

Figure 3. Values observed and estimated by Peleg's model (1988) for temperatures of 45; 55; 65 and $75^{\circ} \mathrm{C}$ as a function of hydration time.

Water absorption increased rapidly in the initial hydration phase, mainly due to the natural capillarity in the outermost layers of the grains, near the pericarp and the diffusion process. According to Resio et al. (2006) and Balbinoti et al. (2018) ${ }^{a, b}$, the water absorption rate depends on the difference between the saturation water content and the water content at a given time which is called driving force. Thus, hydration overtime occurs with increased water content associated with the decreased driving force and, consequently, reduced water absorption rate.

It is also observed, in Figure 3, that, with the increase of the temperature, the water absorption rate increased, intensifying the dynamics of the product hydration phenomenon. 
Similar results were observed in various rice grain hydration processes. (BOTELHO et al. 2010; CHEEVITSOPON \&NOOMHORM (2011); soya beans (QUICAZÁN et al. 2012); chickpeas and beans (SHAFAEI et al. 2016); transgenic and conventional soya beans (FRACASSO et al. 2014); beans (MIANO et al. 2015) and rice (BALBINOTI et al. $2018^{\mathrm{a}, \mathrm{b}}$ ).

A steady increase in water absorption is also observed as the temperature is increased from $45^{\circ} \mathrm{C}$ to 55 and $65^{\circ} \mathrm{C}$. This hig water absorption behavior was observed at 55 and $65^{\circ} \mathrm{C}$. For the temperature range of 55 to $65^{\circ} \mathrm{C}$, red rice has a water content of $28 \%$ from 5 hours of experiment, which according to Amato et al. (2005), Genkawa et al. (2011) and Balbinoti et al. $(2018)^{\text {(a) }}$ the water content in the range $28-30 \%$ is indispensable for the complete gelatinization of rice grain endosperm starch.

Table 3 shows the parameters of Peleg's model, the equilibrium water contents and the statistical parameters $\mathrm{P}, \mathrm{SE}, \mathrm{DQM}$ and $\mathrm{R}^{2}$ for husked rice hydration as a function of the hydration temperature of the hydration process.

From the data analysis of Table 3, it is observed that the Peleg's (1988) model was adequate to describe the hydration process in the husked rice grains of the analyzed variety. It can be verified that the Peleg's model presented $\mathrm{R}^{2}$ values higher than $97.54 \%, \mathrm{P}$ values lower than 4.0473\%, SE values lower than 2.06353 and DQM values lower than 1.30608. It is also noted that the values of SE, DQM, and $\mathrm{P}$ do not show a defined trend with the increase in temperature. According to these parameters $\mathrm{R}^{2}, \mathrm{DQM}, \mathrm{P}$, and $\mathrm{SE}$, it can be stated that the Peleg's model is satisfactory to describe the hydration kinetics of husked red rice.

Table 3. Estimates of Peleg's Model Parameters (1988)

\begin{tabular}{ccccc}
\hline \multicolumn{5}{c}{ Peleg's Model (1988) } \\
\hline Temperature $\left({ }^{\circ} \mathrm{C}\right)$ & 45 & 55 & 65 & 75 \\
$\mathrm{Xo}$ & 14.68878 & 14.72751 & 14.22337 & 13.40719 \\
$\mathrm{k} 1$ & 0.24009 & 0.19438 & 0.10126 & 0.06611 \\
$\mathrm{k} 2$ & 0.02029 & 0.01457 & 0.02326 & 0.02568 \\
$\mathrm{Xe}$ & 63.9741 & 83.3617 & 57.2156 & 52.3480 \\
$\mathrm{DQM}$ & 0.33271 & 0.10374 & 0.75735 & 1.30608 \\
$\mathrm{SE}$ & 0.13837 & 0.01345 & 2.06353 & 1.8703 \\
$\mathrm{P}(\%)$ & 1.1845 & 1.3061 & 2.1323 & 4.0473 \\
$\mathrm{R}^{2}(\%)$ & 99.65 & 99.51 & 99.09 & 97.54 \\
\hline
\end{tabular}


Resende and Corrêa (2007) have studied the hydration kinetics of beans at temperatures of 20, 30,40 and $50{ }^{\circ} \mathrm{C}$ and they showed that the constant $\mathrm{k}_{1}$ of the Peleg's model is related to the mass transfer rate. the lower the $\mathrm{k}_{1}$ values get, the higher the initial water absorption rates are.

Our results, as shown in Table 3, the constants $\mathrm{k}_{1}$ show that its values decreased with increasing temperature, similar behavior was found by Botelho et al. (2010) when investigating the hydration kinetics of the rice variety IRGA 424 at the hydration temperatures of $35,45,55$ and $75{ }^{\circ} \mathrm{C}$. Similar behavior was also found by Sittipod \& Shi (2016) when evaluating the hydration of chickpeas and beans at temperatures of 5, 25 and $45^{\circ} \mathrm{C}$ for three varieties of these beans. Fracasso et al. (2014) have also studied the hydration kinetics of conventional and transgenic soybean at temperatures of $25,35,45,55$ and $65{ }^{\circ} \mathrm{C}$. Similarly to the physical behavior of the kinetic constant k1 evaluated by Quicazán et al. (2012) in evaluating the hydration kinetics of soybean at temperatures of 20,40 and $80{ }^{\circ} \mathrm{C}$ was similar to studies by Resende, Corrêa (2007), Botelho et al. (2010), Sittipod \& Shi (2016), Fracasso et al. (2014) and Balbinoti et al. (2018)

Resende and Corrêa (2007), when investigating the hydration kinetics of beans, proved that the constant value of the Peleg model is related to the maximum water absorption capacity, and the lower its value, the higher the water absorption of the product. Studies by Botelho et al. (2010) for husked rice, variety IRGA 424, followed the same behavior, as did Shafaei et al (2016) when studying the hydration kinetics of beans and chickpeas at temperatures of 5, 25 and $45{ }^{\circ} \mathrm{C}$ for three varieties of beans and chickpeas.

Unlike the studies cited above, the results of Table 3 for the constant $\mathrm{k}_{2}$ showed that the values of $\mathrm{k}_{2}$ did not have a definite behavior when varying the temperature, as well as, the equilibrium water content. Similar results were found by Fracasso et al. (2014) when studying the traditional and transgenic soybeans, they explain that the values found for the constant $\mathrm{k}_{2}$ and the equilibrium water content did not show well-defined behavior with the temperature variation.

Figures 4 and 5 describe the behavior of water absorption kinetics during the red rice hydration step described by the models proposed by Cavalcanti Mata \& Duarte (2018) and Duarte \& Cavalcanti Mata (2018), respectively.

From Figures 4 and 5, similar behaviors are observed when increasing the hydration temperature from $45{ }^{\circ} \mathrm{C}$ to $75{ }^{\circ} \mathrm{C}$. The influence of the hydration temperature is quite significant, with its increase there is a great gain in the absorption rate of water at any hydration time. Raising the temperature from $45^{\circ} \mathrm{C}$ to $55^{\circ} \mathrm{C}$ promotes a slight increase in the water absorption ratio. However, raising the temperature from $55^{\circ} \mathrm{C}$ to $65{ }^{\circ} \mathrm{C}$ and $75{ }^{\circ} \mathrm{C}$ increases considerably the absorption rate of water. 


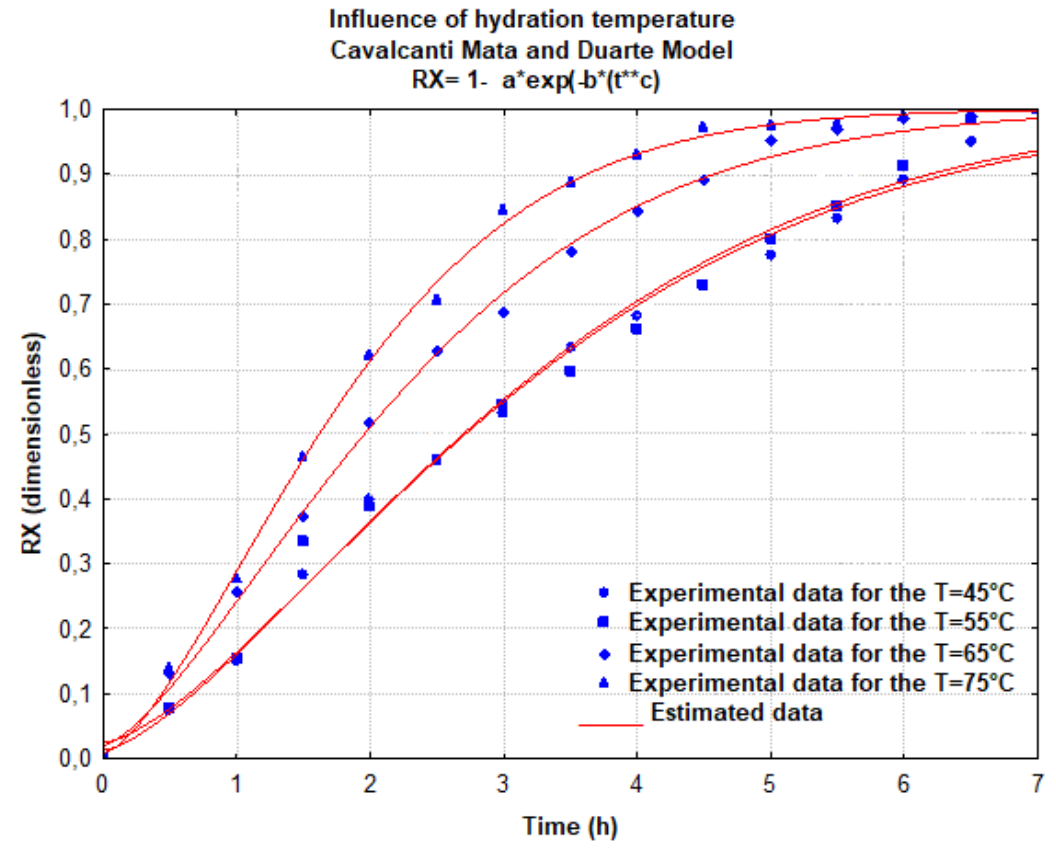

Figure 4. Water absorption kinetics proposed by Cavalcanti Mata \& Duarte's model (2018)

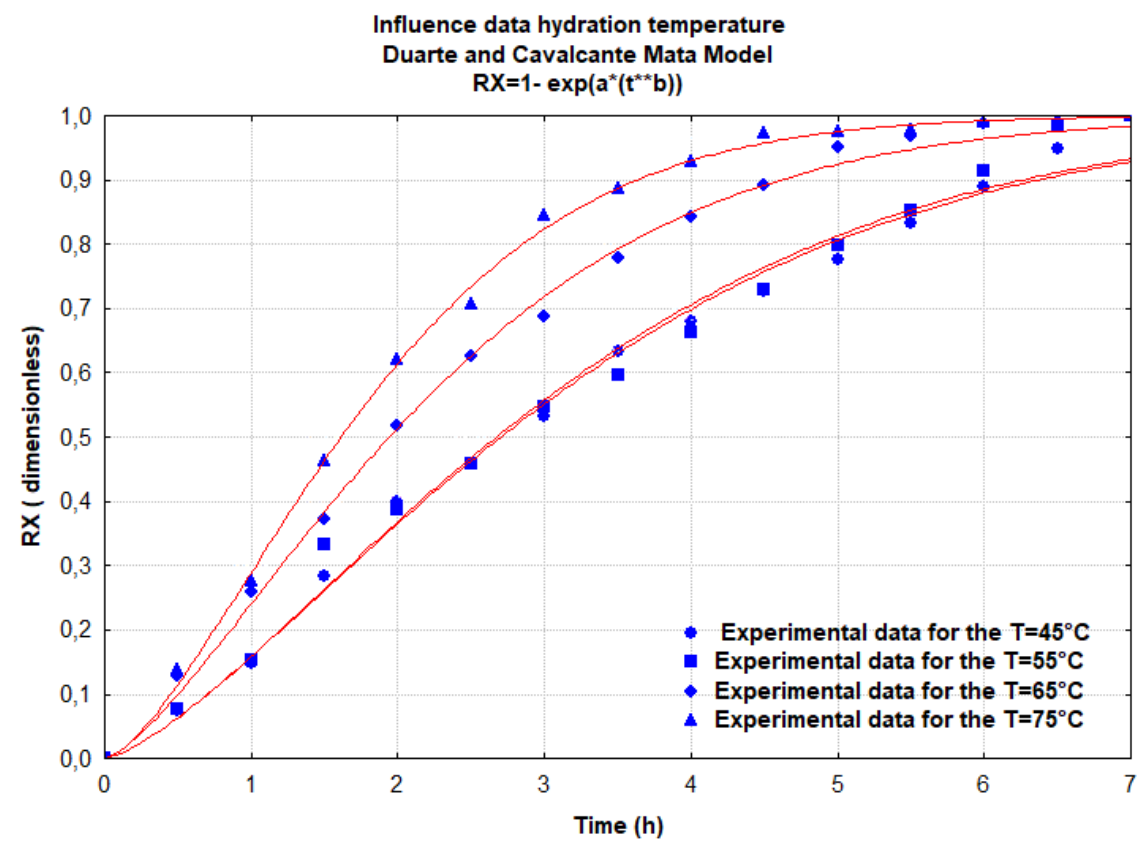

Figure 5. Water absorption kinetics proposed by Duarte \& Cavalcanti Mata's Model (2018)

Tables 4 and 5 show the statistical values of the coefficients of determination $\left(R^{2}\right)$, mean square deviation (DQM), relative mean error $(\mathrm{P})$ and the estimate of standard deviation (SE) for models adjusted for red rice absorption kinetics at different temperatures. 
Table 4. Estimates of the Cavalcanti Mata \& Duarte's Model Parameters (2018)

\begin{tabular}{ccccc}
\hline \multicolumn{5}{c}{ Cavalcanti Mata \& Duarte's Model (2018) } \\
\hline Temperature $\left({ }^{\circ} \mathrm{C}\right)$ & 45 & 55 & 65 & 75 \\
$\mathrm{~A}$ & 0.9872 & 0.9754 & 0.9794 & 0.9913 \\
$\mathrm{~B}$ & -0.1627 & -0.1548 & -0.2564 & -0.3328 \\
$\mathrm{C}$ & 1.4324 & 1.4741 & 1.4368 & 1.4993 \\
$\mathrm{DQM}$ & $2.76 \times 10^{-2}$ & $3.67 \times 10^{-2}$ & $1.67 \times 10^{-2}$ & $8.41 \times 10^{-2}$ \\
$\mathrm{SE}$ & $3.08 \times 10^{-2}$ & $4.10 \times 10^{-2}$ & $1.86 \times 10^{-2}$ & $9.40 \times 10^{-4}$ \\
$\mathrm{P}(\%)$ & 3.97 & 4.79 & 2.85 & 15.88 \\
$\mathrm{R}^{2}(\%)$ & 99.21 & 98.64 & 99.74 & 99.87 \\
\hline
\end{tabular}

Table 4 shows the estimates of parameters $\mathrm{a}, \mathrm{b}$ and $\mathrm{c}$ of the model proposed by Cavalcanti Mata \& Duarte (2018). Table 5 shows the estimates of parameters a and b of the model proposed by Duarte \& Cavalcanti Mata (2018). It is observed by the coefficients of the parameters expressed in Tables 4 and 5 that there is no clear tendency with the increase of the hydration temperature.

The mathematical model proposed by Cavalcanti Mata \& Duarte (2018) adjusted to the experimental data presented coefficients of determination greater than $98.64 \%$, the relative mean error $(\mathrm{P})$ values are less than $15.88 \%$ the deviation values quadratic mean (DQM) values are less than $8.41 \times 10^{-2}$ and the standard deviation (SE) estimate values are less than $4.00 \times 10^{-2}$. The values of statistical parameters for the mathematical model proposed by Duarte and Cavalcanti Mata (2018) presented coefficients of determination greater than $98.58 \%$, the relative mean error $(\mathrm{P})$ values are less than 5.8571, mean square deviation (DQM) values are less than $37.49 \times 10^{-3}$ and standard deviation (SE) estimates are less than $40.00 \times 10^{-3}$. Given the results presented, it is observed that the models proposed by Cavalcanti Mata \& Duarte (2018) and Duarte \& Cavalcanti Mata (2018) represent well the absorption kinetics of red rice. 
Table 5. Parameter Estimates of the Duarte \& Cavalcanti Mata’s Model (2018)

\begin{tabular}{ccccc}
\hline \multicolumn{5}{c}{ Duarte \& Cavalcanti Mata's Model (2018) } \\
Temperature $\left({ }^{\circ} \mathrm{C}\right)$ & 45 & 55 & 65 & 75 \\
$\mathrm{~A}$ & -0.1721 & -0.1734 & -0.2754 & -0.3417 \\
$\mathrm{~B}$ & 1.4013 & 1.4102 & 1.3909 & 1.4792 \\
$\mathrm{DQM}$ & $27.91 \times 10^{-3}$ & $37.49 \times 10^{-3}$ & $17.71 \times 10^{-3}$ & $12.09 \times 10^{-3}$ \\
$\mathrm{SE}$ & $30.0 \times 10^{-3}$ & $40.00 \times 10^{-3}$ & $19.0 \times 10^{-3}$ & $12.1 \times 10^{-3}$ \\
$\mathrm{P}(\%)$ & 4.5433 & 5.8571 & 3.4044 & 2.1525 \\
$\mathrm{R}^{2}(\%)$ & 99.20 & 98.58 & 99.71 & 99.87 \\
\hline
\end{tabular}

\subsection{Structural Evaluation by X-ray Diffraction of Parboiled Rice}

The different parboiling conditions of red rice were analyzed using the X-ray diffraction technique to observe the changes in crystalline shape and structure that occurred after the parboiling process of red rice subjected to the different parboiling conditions.

Figures 6 to 8 show the diffractograms of parboiled rice starch submitted to different autoclave conditions (autoclave residence times of 14, 22 and 30 minutes) and drying temperature $\left(50,60\right.$ and $\left.70{ }^{\circ} \mathrm{C}\right)$. It is also presented the diffractogram of the red rice before the parboiling process submitted to drying at $50{ }^{\circ} \mathrm{C}$ and hydration at $55^{\circ} \mathrm{C}$ for 7 hours.

Figures 6 to 8 show the characteristics of the x-ray diffractogram for the parboiled red rice sample submitted to 14, 22 and 30 minutes of autoclave and drying temperatures of 50,60 and $70{ }^{\circ} \mathrm{C}$. For better visualization of the differences that the autoclave residence time of 14 , 22 and 30 minutes and the drying temperatures of 50,60 and $70{ }^{\circ} \mathrm{C}$ promotes concerning the $\mathrm{x}$-ray diffractogram of hydrated red rice at $55^{\circ} \mathrm{C}$ for 7 hours. 


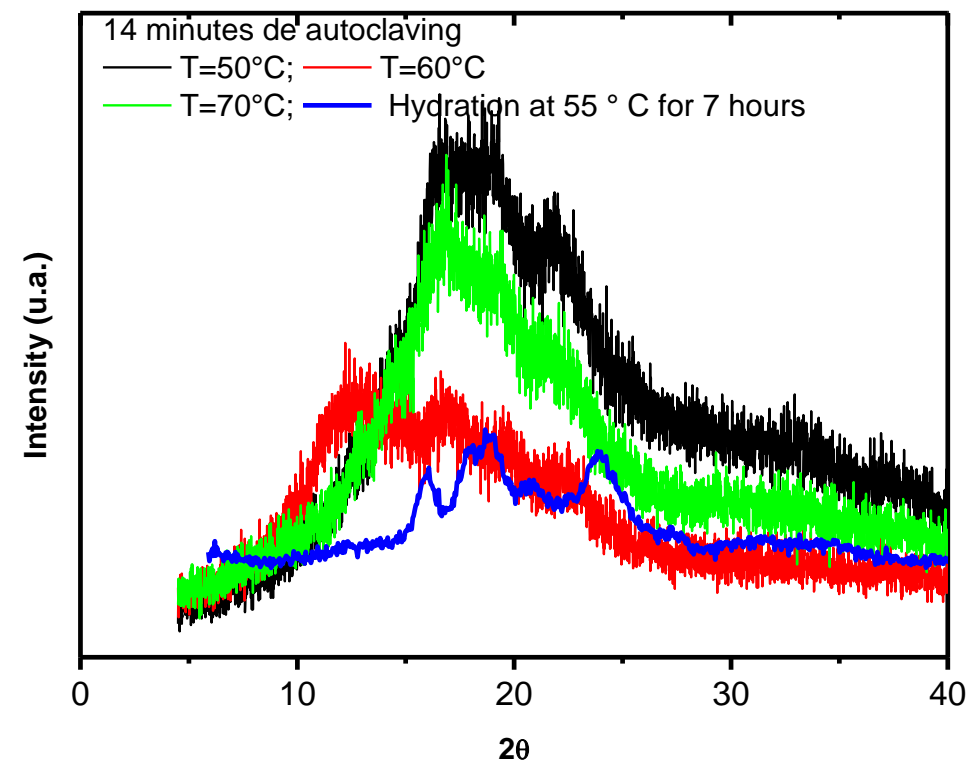

Figure 6. X-ray diffractograms of red rice submitted to parboiling process with autoclave residence time for 14 minutes and drying temperatures of 50,60 and $70{ }^{\circ} \mathrm{C}$

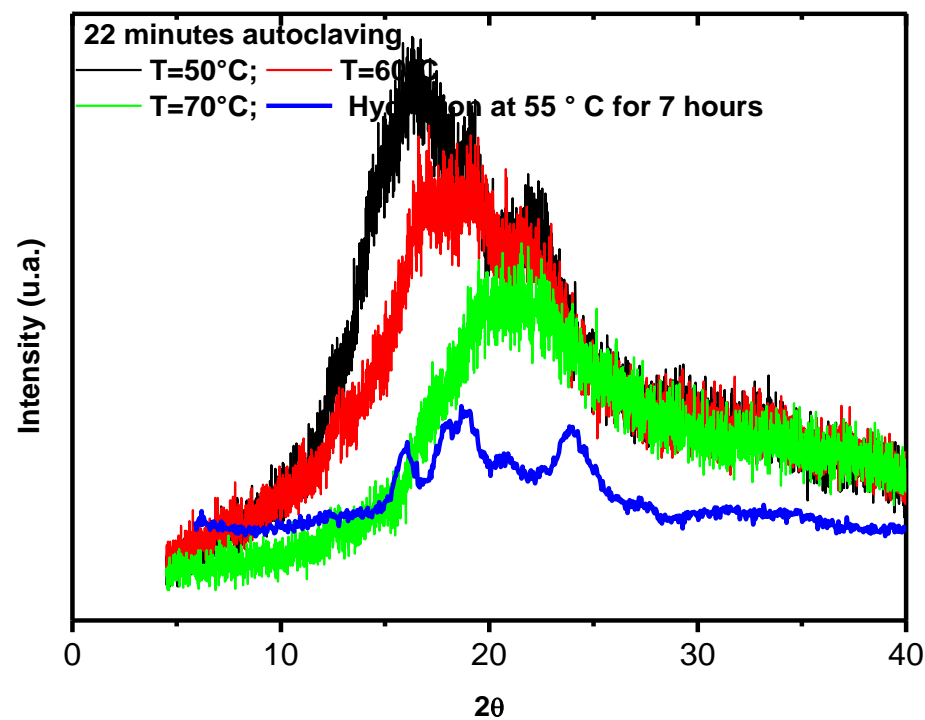

Figure 7. X-ray diffractograms of red rice submitted to parboiling process with autoclave residence time for 22 minutes and drying temperatures of 50,60 and $70{ }^{\circ} \mathrm{C}$ 


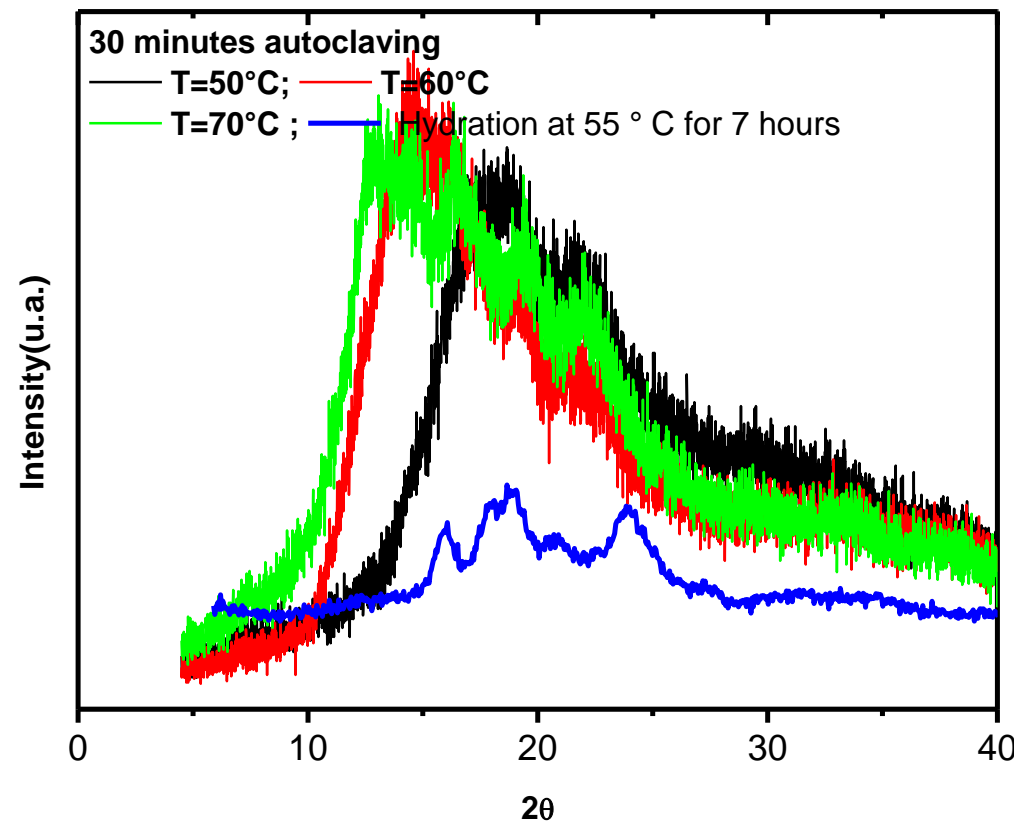

Figure 8. X-ray diffractograms of red rice submitted to parboiling process with autoclave residence time for 30 minutes and drying temperatures of 50,60 and $70{ }^{\circ} \mathrm{C}$

According to the data presented in Table 6, the observed peaks for the drying temperature at $50^{\circ} \mathrm{C}$ were $2 \theta$ equal to $16.77^{\circ} ; 19.20^{\circ} ; 21.82^{\circ}$ (for 14 minutes of autoclave), while for 22 minutes of autoclave they were at $2 \theta$ equal to $16.41^{\circ}, 19.29^{\circ}, 21.91^{\circ}$; for 30 minutes of autoclave were at $2 \theta$ equal to $18^{\circ} ; 19^{\circ} ; 22^{\circ}$. Peak intensity data for drying temperature at $60{ }^{\circ} \mathrm{C}$ were $2 \theta$ equal to $16.96^{\circ} ; 19.47^{\circ} ; 22.17^{\circ}$ (for 14 minutes autoclave), peak intensities at $2 \theta$ equal to $17.14^{\circ}, 19.29^{\circ}, 21.64^{\circ}$ (for 22 minutes autoclave) and peak intensities at $2 \theta$ equal to $16.6^{\circ} ; 17.4^{\circ}, 19.1^{\circ}, 21.6^{\circ}$ (for 30 minutes autoclave).

Table 6. Peak intensity at $2 \theta$ diffraction angles for red rice samples submitted to parboiling process with an autoclave residence time of 14, 22 and 30 minutes for drying temperatures of 50,60 and $70{ }^{\circ} \mathrm{C}$

\begin{tabular}{cccc}
\multirow{2}{*}{$\begin{array}{c}\text { Temperature } \\
\left({ }^{\circ} \mathrm{C}\right)\end{array}$} & \multicolumn{3}{c}{ Peak intensities for different autoclaving time } \\
\cline { 2 - 4 } & 14 minutes & 22 minutes & 30 minutes \\
50 & $16.77^{\circ} ; 19.20^{\circ} ; 21.82^{\circ}$ & $16.41^{\circ} ; 19.29^{\circ} ; 21.91^{\circ}$ & $18^{\circ} ; 19^{\circ} ; 22^{\circ}$ \\
60 & $16.96^{\circ} ; 19.47^{\circ} ; 22.17^{\circ}$ & $17.14^{\circ} ; 19.29^{\circ} ; 21.64^{\circ}$ & $16.6^{\circ} ; 17.4^{\circ} ; 19.1^{\circ} ; 21.6^{\circ}$ \\
70 & $16.77^{\circ} ; 19.29^{\circ} ; 21.19^{\circ}$ & $19.84^{\circ} ; 21.55^{\circ} ; 22.28^{\circ} 17.01^{\circ} ; 17.9^{\circ} ; 19.1^{\circ} ; 21.7^{\circ}$
\end{tabular}


$70^{\circ} \mathrm{C}$, for the same autoclave time $(14,22$ or 30 minutes), the structures reduce the crystallinity of 39, 34 and 33\% (for 14 minutes autoclave), 32, 32 and 29\% (for 22 minutes autoclave) and 16, 14 and $11 \%$ (for 30 minutes), respectively at drying temperatures of 50,60 and $70{ }^{\circ} \mathrm{C}$. These results show that reductions in crystallinity lead to the morphology of parboiled rice starch to be a structure closer to the characteristics of low crystallinity approaching the profile of an amorphous structure.

Similarly, reduction in crystallinity is also observed when the autoclaving time is increased by 14,22 and 30 minutes at drying temperatures of 50, 60 and $70{ }^{\circ} \mathrm{C}$. Crystallinity reduces from $39 \%, 32 \%$ and $16 \%$ (for 14 minutes autoclave), 34\%, 32\% and $14 \%$ (for 22 minutes autoclave) and $33 \%, 29 \%$ and $11 \%$ (for 30 minutes autoclave) at drying temperatures 50, 60 or $70{ }^{\circ} \mathrm{C}$, respectively.

The degrees of intensity of the diffractograms shown in Figures 6 to 8 and the crystallinity contained in Table 7 showed that the parboiling process under the evaluated conditions (autoclave time 14, 22 and 30 minutes and drying temperatures of 50, 60 and $70{ }^{\circ} \mathrm{C}$ ) evidences the gelatinization of starch in red rice. Starch type A has been disrupted by amylopectin crystallites, similarly to the results of Dutta et al. (2015).

\subsection{Morphological Analysis by Scanning Electron Microscopy (SEM)}

Figures 10(a) and 10(b) show the micrographs of the surface in a sample of the traditional fresh in-shell red rice and surface in a sample of dried red rice at $50{ }^{\circ} \mathrm{C}$, respectively. In Figures $10(\mathrm{c}), 10(\mathrm{~d}), 10(\mathrm{e})$ and10 (f), it is observed that red rice was pre-dried at $50{ }^{\circ} \mathrm{C}$ and hydrated red rice at $45^{\circ} \mathrm{C}, 55^{\circ} \mathrm{C}, 65^{\circ} \mathrm{C}$ and $75^{\circ} \mathrm{C}$ for 7 hours, respectively.

It is observed in Figures 10 (a) and 10 (b) that the surface of the red rice is all irregular with some "thorns" and white dots that are silica. According to Angel et al. (2009), rice husk is a protective coating composed of four structural layers.

From Figures 10 (c), 10 (d), 10 (e) and 10 (f) it is observed that hydration during 7 hours of immersion gave the red rice grains elimination of the "thorns". As well as the hydration in the temperature range of 45 to $75^{\circ} \mathrm{C}$ provided an alteration of its morphological structure, but there is no evidence by micrographs that characterize the occurrence of complete gelatinization of chemical structures. When the grain reaches this condition, starch complexes are broken down and the molecules consequently adopt random orientation, allowing cracks and intermolecular spaces in the grain to be filled, enabling a solid structure and high degree of compaction. This gelatinization condition was observed in the studies of the rice hydration stage conducted by Wu et al. (2010), Genkawa et al. (2011), Pineda - Gómes et al (2012) and Balbinoti et al. (2018) $)^{\mathrm{a}, \mathrm{b}}$. 


\section{MInstitute ${ }^{\text {Macrothink }}$}

Journal of Agricultural Studies

ISSN 2166-0379

2020, Vol. 8, No. 2

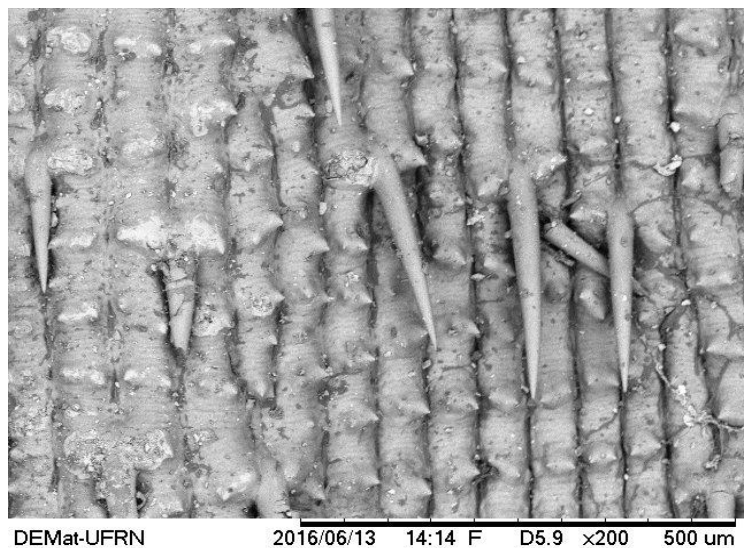

(a)

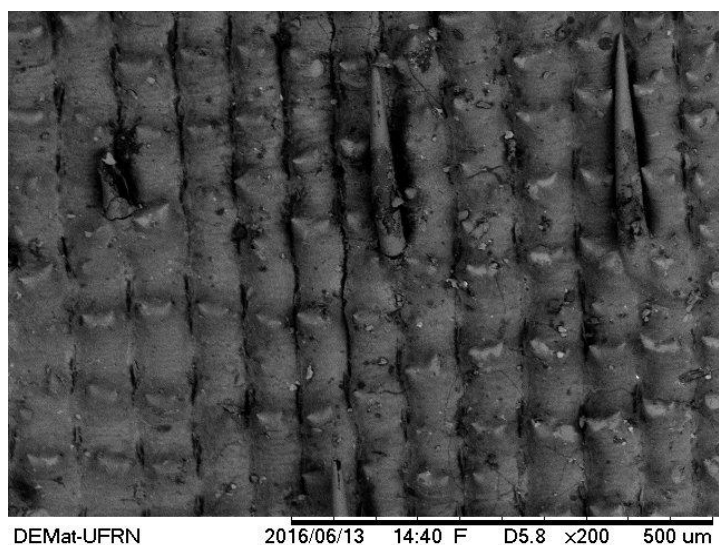

(c)

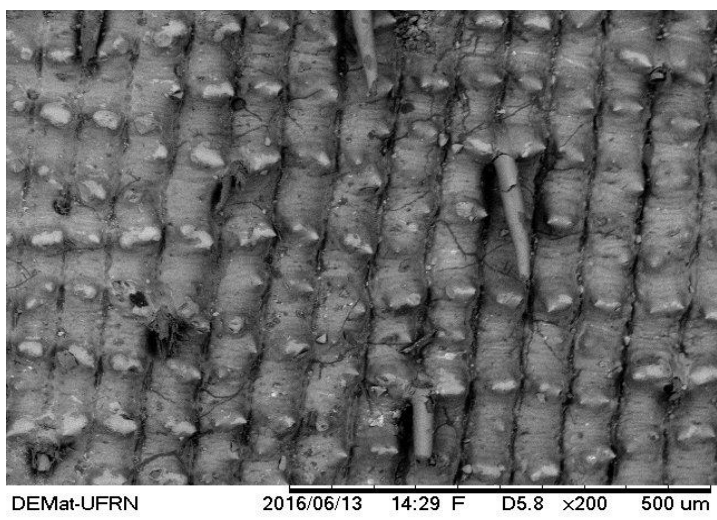

(e)

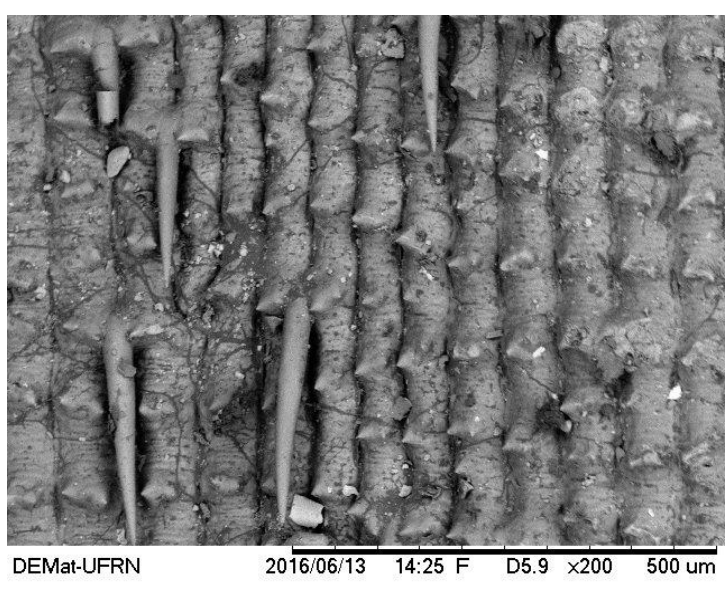

(b)

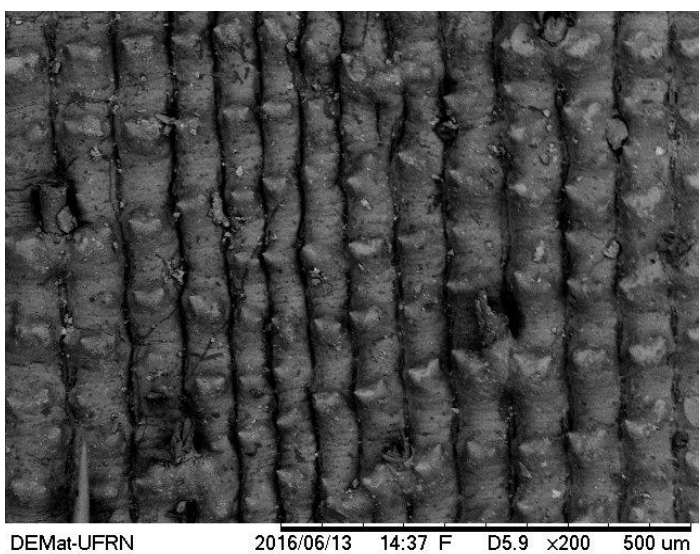

(d)

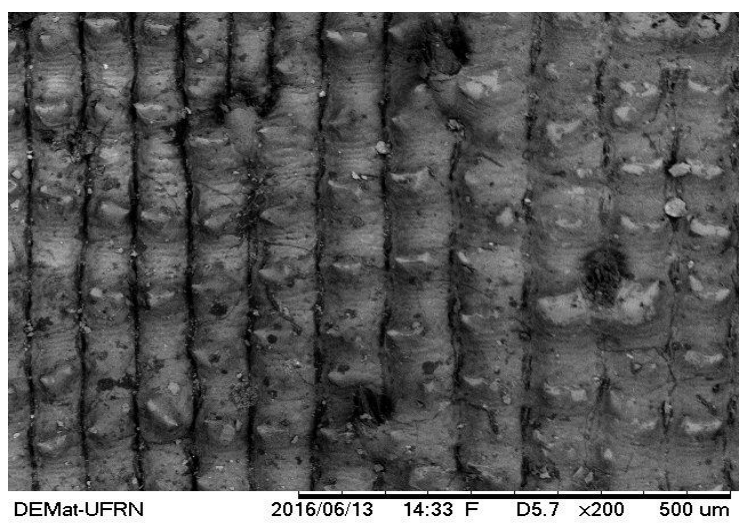

(f)

Figure 10. Micrographs of red husked rice: (a) fresh; (b) dried at $50^{\circ} \mathrm{C}$; (c) hydrated at $45^{\circ} \mathrm{C}$; (d) hydrated at $55^{\circ} \mathrm{C}$; (e) hydrated at $65^{\circ} \mathrm{C}$; (f) hydrated at $75^{\circ} \mathrm{C}$ 


\section{MInstitute ${ }_{\text {Mnk }}^{\text {Macrothink }}$}

Journal of Agricultural Studies

ISSN 2166-0379

2020, Vol. 8, No. 2

Figure 11 shows the micrographs of red rice autoclaved for 14, 22 and 30 minutes and drying temperatures of 50,60 and $70^{\circ} \mathrm{C}$. There are differences in the morphological structure of red rice when submitted to different autoclave times (14, 22 and 30 minutes) and drying temperatures $\left(50,60\right.$ and $\left.70{ }^{\circ} \mathrm{C}\right)$.

As can be seen in Figure 11, vaporization of red rice with an autoclave residence time of 14, 22 and 30 minutes provides breakdown of starch complexes, consequently, the molecules adopt random orientation, allowing intermolecular cracks and spaces in the grain to be filled, enabling the emergence of a solid and high-grade structure (Sittipod \& Shi (2016), BALBINOTI et al. (2018) ${ }^{\mathrm{a}, \mathrm{b}}$ ).

Given these micrographs, it is observed that the parboiled red rice, which was autoclaved for 14, 22 and 30 minutes and dried at 50,60 and $70^{\circ} \mathrm{C}$, reached complete starch gelatinization. As is also observed, the vaporization time (autoclaving time) 14, 22 and 30 minutes and the drying temperature 50,60 and $70{ }^{\circ} \mathrm{C}$ intensifies the modification of the starch amylaceous structure, confirming the results of Lamberts et. al. (2009) and Sittipod \& Shi (2016).

\section{Autoclaving for 14 minutes}

$50^{\circ} \mathrm{C}$

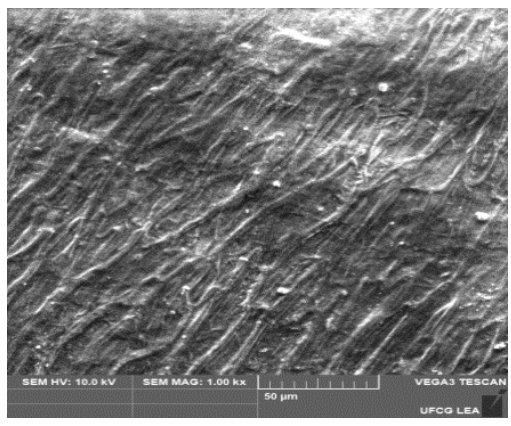

$60^{\circ} \mathrm{C}$

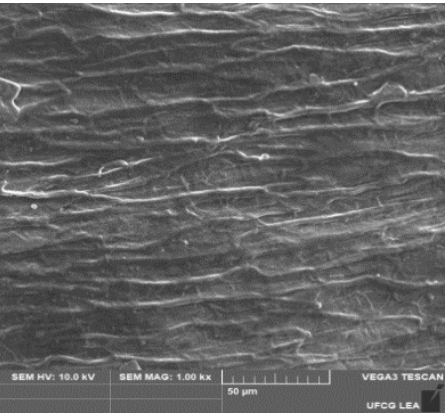

$70^{\circ} \mathrm{C}$

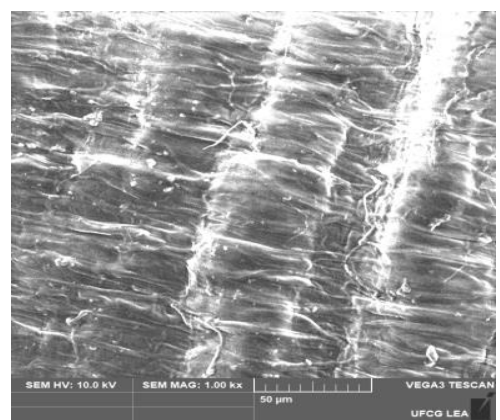

Autoclaving for 22 minutes

$50^{\circ} \mathrm{C}$

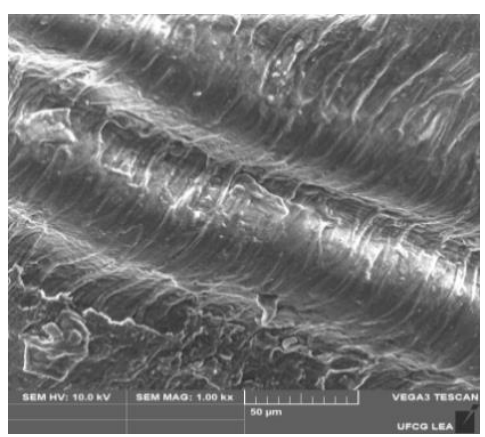

$60^{\circ} \mathrm{C}$

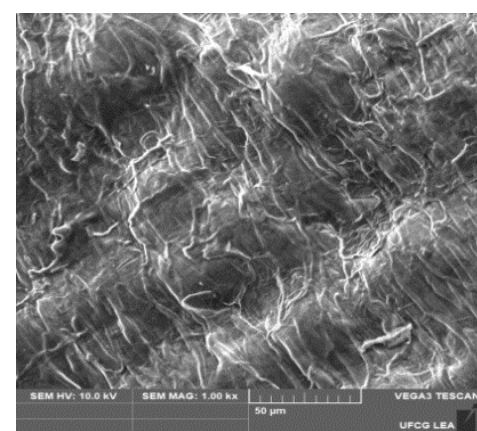

$70^{\circ} \mathrm{C}$

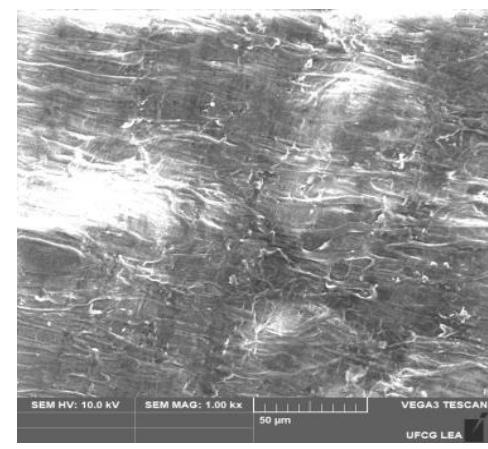

Autoclaving for 30 minutes 
$50^{\circ} \mathrm{C}$

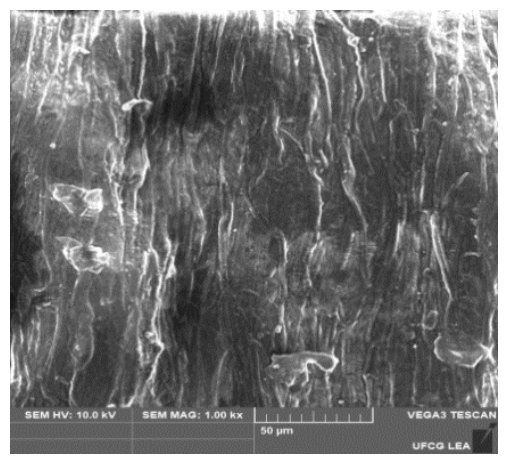

$60^{\circ} \mathrm{C}$

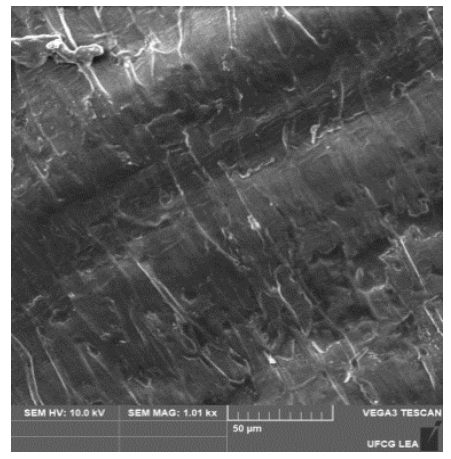

$70^{\circ} \mathrm{C}$

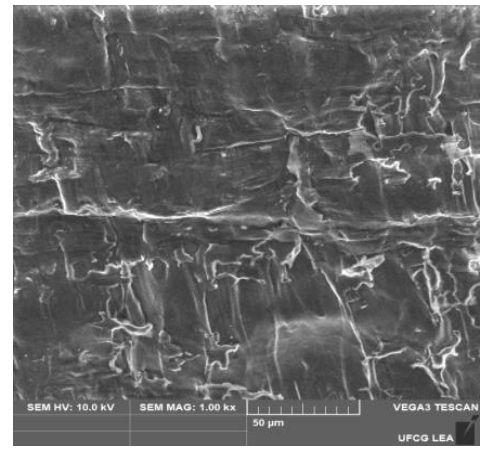

Figure 11. Micrographs of the morphological structure of red rice along the parboiling process with autoclave residence time for 14, 22 and 30 minutes and drying temperatures of 50,60 and $70{ }^{\circ} \mathrm{C} ; 1 \mathrm{kx}$ magnification

\section{Conclusion}

1. The X-ray diffraction characterization technique showed that samples of hydrated husked rice at temperatures from $45{ }^{\circ} \mathrm{C}$ to $75{ }^{\circ} \mathrm{C}$ show characteristic diffractogram peaks of starch cereals type A.

2. Morphological analysis by scanning electron microscopy (SEM) showed that for all samples of hydrated husked rice at temperatures from $45^{\circ} \mathrm{C}$ to $75^{\circ} \mathrm{C}$ there were changes in its morphological structure.

3. In the mathematical modeling, Peleg's (1988) model satisfactorily described the hydration kinetics of red husked rice, according to the evaluation of the statistic parameters $\mathrm{P}, \mathrm{SE}$, DQM e $\mathrm{R}^{2}$.

4. In the mathematical modeling, the evaluation of the statistical parameters $\mathrm{P}, \mathrm{SE}, \mathrm{DQM}$, and $\mathrm{R}^{2}$ confirmed that the models proposed by Cavalcanti \& Duarte and Cavalcanti Mata $\&$ Duarte (2018) presented a better description for the results in all temperature range evaluated.

5. The X-ray diffraction characterization technique for parboiled red rice showed the alteration of X-ray diffractograms, confirming the reduction of the parboiled red rice crystallinity, making the starchy structure of red rice very distinct from the starch Type A structure.

6. Morphological analyzes by scanning electron microscopy (SEM) showed that for all autoclave time conditions 14, 22 and 30 minutes and drying temperatures of 50, 60 and $70^{\circ} \mathrm{C}$ of husked red rice gelatinization process of the starch was confirmed.

\section{Acknowledgement}

The authors thank the Laboratories of Plant Physiology and Plant Pathology, both belonging 
to the Academic Unit of Agronomy of the Federal University of Campina Grande, UFCG Pombal. As well as the Nanotechnology Laboratory of the Northeast Center for Strategic Technologies - Cetene and the Multifunctional Materials and Numerical Experimentation Laboratory - ECT, UFRN. The authors would like to thank the Food Engineering Laboratory of the Federal University of Campina Grande, UFCG.

\section{References}

Alberto, C. M., Jorge, A. G., \& Pedro, E. D. A. (2015). Correlation between morphology, hydration kinetics and mathematical models on Andean lupin (Lupinus mutabilis Sweet) grains, LWT - Food Science and Technology, 61(2), 290-298. https://doi.org/10.1016/j.lwt.2014.12.032

Aline, M., Renan, G. M., Alexandre, U., \& Suzana, M. (2019). Films based on cassava starch reinforced with soybean hulls or microcrystalline cellulose from soybean hulls, Food Packaging and Shelf Life, 20, 100321. https://doi.org/10.1016/j.fps1.2019.100321

Amanda, L. O., Beatriz, G. C., Emily, Z. da S., Isabela, R. G., Raquel, L. V., Pedro, E., \& Duarte, A. (2013). Modelling the effect of temperature on the hydration kinetic of adzuki beans (Vigna angularis), Journal of Food Engineering, 118(4), 417-420. https://doi.org/10.1016/j.jfoodeng.2013.04.034

Amato, G. W., \& Elias, M. C. (2005). Parboilização do arroz. Porto Alegre: Editora Ricardo Lenz Ziede, p.160, 2005.

Andrea, C. R., Roberto, J. A., \& Constantino, S. (2006). Hydration kinetics of amaranth grain, Journal of Food Engineering, 247-253, https://doi.org/10.1016/j.jfoodeng.2004.12.003.

Ayamdoo, A. J., Demuyakor, B., Saalia, F. K., \& Francis, A. (2014). Effect of Varying Parboiling Conditions on the Cooking and Eating/Sensory Characteristics of Jasmine 85 and Nerica 14 Rice Varieties. American Journal of Food Technology, 9, 1-14. https://doi.org/10.3923/ajft.2014.1.14

Balbinoti $^{\mathrm{a}}$, C. V., Jorge, L. M. M., \& Jorge, R. M. M. (2018). Modeling the hydration step of the rice (Oryza sativa) parboiling Process. Journal of Food Engineering, 216, 81-89, https://doi.org/10.1016/j.jfoodeng.2017.07.020

Bartz, J., Madruga, K. M., Klein, B., Pinto, V. Z., \& Dias, Á. R. G. (2012). Propriedades de pasta de amidos de arroz nativo e acetilados. Brazilian Journal of Food Technology, 15, 78-83. Epub November 30, 2012. https://doi.org/10.1590/S1981-67232012005000040

Botelho, F. M., Corrêa, P. C., Goneli, A. L. D., Martins, M. A., \& Baptestini, F. M. (2010). Análise da hidratação do arroz na parboilização. Food Science and Technology, 30(3), 713-718. https://doi.org/10.1590/S0101-20612010000300023

Brasil. Ministério da Agricultura, Pecuária e Abastecimento. Secretaria de Defesa Agropecuária. Regras para análise de sementes. Brasília: Ministério da Agricultura, Pecuária e Abastecimento, (2009). 398 p. 
Bruna, A., Josiane, B., Marjana, R., Jarine, A. do E., Vânia, Z. P., Elessandra, da R. Z., \& Alvaro, R. G. D. (2015). Impact of heat-moisture treatment on rice starch, applied directly in grain paddy rice or in isolated starch, LWT - Food Science and Technology, 60(2), 708-713, https://doi.org/10.1016/j.lwt.2014.10.059

Buggenhout, J., Brijs, K., Celus, I., \& Delcour, J. A. (2013). The breakage susceptibility of raw and parboiled rice: A review. (2013). Journal of Food Engineering, 17(3), 304-315, https://doi.org/10.1016/j.jfoodeng.2013.03.009

Carola, C., Mara, L., Gustavo, V., \& Barbosa-Cánovas, M. M. (2016). Physical and structural changes induced by high pressure on corn starch, rice flour and waxy rice flour, (2016). Food Research International, 85, 95-103, https://doi.org/10.1016/j.foodres.2016.04.018

Cláudia, L. L., Jordana, C. S., \& Isabel, C. T. (2017). Starch content affects physicochemical properties of corn and cassava starch -based films, Industrial Crops and Products, 109, 619-626. https://doi.org/10.1016/j.indcrop.2017.09.020

Coutinho, M. R. (2006). Modelagem, simulação e análise da hidratação de grãos de soja. Maringá, PR, 178 p. Tese (Doutorado em Engenharia Química) - Departamento de Engenharia Química, Universidade Estadual de Maringá - UEM.

Dors, G. C., Pinto, Renata, H., \& Badiale-Furlong, E. (2009). Influência das condições de parboilização na composição química do arroz. Food Science and Technology, 29(1), 219-224. https://doi.org/10.1590/S0101-20612009000100034

Ejebe, C., Danbaba, N., \& Ngadi, M. (2015). Effect of steaming on physical and thermal properties of parboiled rice. European International Journal of Science and Technology, 4(4). https://www.researchgate.net/publication/271840990_Effect_of_Steaming_on_Physical_and_ Thermal_Properties_of_Parboiled_Rice_from_Nigeria/citation/download

Ekkapong, C., \& Athapol, N. (2011). Kinetics of Hydration and Dimensional Changes of Brown Rice. (2011). Journal of Food Processing and Preservation, 35, 840-849, https://doi.org/10.1111/j.1745-4549.2011.00537

Felipe, F. L., \& Cristina, T. A. (2010). Effect of melt-processing and ultrasonic treatment on physical properties of high-amylose maize starch, Ultrasonics Sonochemistry, 17(4), 637-641. https://doi.org/10.1016/j.ultsonch.2010.01.001

Flávia, F. P., Nathan, L. V., Jose, De J. B., Vânia, Z. P., Delilah, W., Tina, W., .. Moacir, C. E. (2016). Polishing and parboiling effect on the nutritional and technological properties of $\begin{array}{lllll}\text { pigmented } \quad \text { rice. } & \text { Food } & \text { Chemistry, } & 191, & 112 .\end{array}$ https://doi.org/10.1016/j.foodchem.2015.02.047

Ghafoor, M., Misra, N.N., Mahadevan, K., \& Tiwari, B. K. (2014). Ultrasound assisted hydration of navy beans (Phaseolus vulgaris), Ultrasonics Sonochemistry, 21(1), 409-414, ISSN 1350-4177. https://doi.org/10.1016/j.ultsonch.2013.05.016

Helbig, E., Romano, C. M., Radünz, A. L., Rutz, D., Dias, A. R. G., \& Elias, M. C. (2008). Efeitos da Amilose e do Processamento na Formação e Estabilidade do Amido Resistente em 
Arroz. Campinas. Brazilian Journal of Food Technology, 10(4), 296-301. https://doi.org/10.5433/1679-0359.2013v34n3p1167

Himjyoti, D., \& Charu, L. M. (2014). Traditional Parboiled Rice-Based Products Revisited: Current Status and Future Research Challenges. Rice Science, 21(4), 2014, 187-200. https://doi.org/10.1016/S1672-6308(13)60191-2

Huang, S. L., Jao, C. L., \& Hsu, K. C.(2009). Effects of Hydrostatic Pressure/Heat Combinations on Water Uptake and Gelatinization Characteristics of Japonica Rice Grains: A $\begin{array}{lllll}\text { Kinetic Study. Journal } & \text { Food }\end{array}$ https://doi.org/10.1111/j.1750-3841.2009.01329.x

Hulleman, S. H. D., Kalisvaart, M. G., Janssen, F. H. P., Feil, H., \& Vliegenthart, J. F. G. (1999). Origins of B-type crystallinity in glycerol-plasticised, compression-moulded potato starches, Carbohydrate Polymers, 39(4), 351-360. ISSN 0144-8617, https://doi.org/10.1016/S0144-8617(99)00024-7

Jideani, V. A., \& Mpotokwana, S. M. (2009). Modeling of water absorption of Botswana bambara varieties using Peleg's equation, Journal of Food Engineering, 92(2), 182-188. https://doi.org/10.1016/j.jfoodeng.2008.10.040

Jun, H., Zhao, L. X., Man, J. M., Wang, J., Zhou, W. D., Huai, H. Y., \& Wei, C. X. (2015). Comparison of physicochemical properties of B-type nontraditional starches from different sources. International Journal of Biological Macromolecules, 78, 165-172, ISSN 0141-8130. https://doi.org/10.1016/j.ijbiomac.2015.04.006

Kale, S. J., Jha, S. K., Jha, G. K., Sinha, J. P., \& Lal, S. B. (2015). Soaking Induced Changes in Chemical Composition, Glycemic Index and Starch Characteristics of Basmati Rice. Rice Science, 22(5), 227-236. https://doi.org/10.1016/j.rsci.2015.09.002

Les, C., Jaroslav, B., \& Hayfa, S. (2008). Mary Chiming Tang, Form and functionality of starch, (2009). Food Hydrocolloids, 23(6), 1527-1534, https://doi.org/10.1016/j.foodhyd.2008.09.016

Lieve, L. Sara, V., Gomand, V. D., \& Jan, A. D. (2009). Presence of Amylose Crystallites in Parboiled Rice. Journal of Agricultural and Food Chemistry, 57(8), 3210-3216. https://doi.org/10.1021/jf803385m

Lima, B. N. B., C., Thayná, B., C. N., Roberto, P., T., Maria, I. B., \& Pierucci, A. P. T. (2012). Estudo do amido de farinhas comerciais comestíveis. Polímeros, 22(5), 486-490. Epub. October 18. https://doi.org/10.1590/S0104-14282012005000062

López-Córdoba, A., Medina-Jaramillo, C., Piñeros-Hernandez, D., \& Goyanes, S. (2017). Cassava starch films containing rosemary nanoparticles produced by solvent displacement method. Food Hydrocolloids, 71, 26-34. https://doi.org/10.1016/j.foodhyd.2017.04.028

Machado, B. A. S., Reis, J. H. O., Silva, J. B., da, Cruz, L. S., Nunes, I. L., Pereira, F. V., \& Druzian, J. I. (2014). Obtenção de nanocelulose da fibra de coco verde e incorporação em filmes biodegradáveis de amido plastificados com glicerol. Química Nova, 37(8), 1275-1282. 
https://doi.org/10.5935/0100-4042.20140220

María, C. C., María, C. A., Alain, D., \& Adriana, N. M. (2018). Composite and nanocomposite films based on amaranth biopolymers. Food Hydrocolloids, 74, 159-167, https://doi.org/10.1016/j.foodhyd.2017.07.013

Martínez, A., Juan, D., Pineda, V., Tatiana, G., Junkes, J. A., \& Hotza, D. (2009). Caracterização de cinza obtida por combustão de casca de arroz em reator de leito fluidizado. Química Nova, 32(5), 1110-1114, https://doi.org/10.1590/S0100-40422009000500006

Matty, D., Espérance, Z., Pieter, R., Maimouna, N., Paul, Van M., \& Wim, V. (2012). Consumer valuation of improved rice parboiling technologies in Benin. Food Quality and Preference, 23(1), 63-70. https://doi.org/10.1016/j.foodqual.2011.07.005

Narpinder, S., Jaspreet, S., Lovedeep, K., Navdeep, S. S., \& Balmeet, S. G. (2003). Morphological, thermal and rheological properties of starches from different botanical sources, 2003, Food Chemistry, 81(2), 219-231, https://doi.org/10.1016/S0308-8146(02)00416-8

Omoto, E. S., Andrade, C. M. G., Jorge, R. M. M., Coutinho, M. R., Paraíso, P. R., \& Jorge, L. M. de M. (2009). Modelagem matemática e análise da hidratação de grãos de ervilha. Food Science and Technology, 29(1), 12-18. https://doi.org/10.1590/S0101-20612009000100003

Pagnan, M. F., Bassinello, P. Z., \& Prudencio, S. H. (2015). Características sensoriais, físicas e químicas e aceitação de arroz irrigado ou de terras altas. Pesquisa Agropecuária Brasileira, 50(10), 979-988. https://doi.org/10.1590/S0100-204X2015001000014

Pascual, C. S. C. I. (2010). Efeitos da parboilização do arroz (Oryza sativa L.) integral sobre os compostos bioativos e a disponibilidade do amido. 102 f. Tese (Doutorado em Bromatologia) - Universidade de São Paulo, São Paulo, 2010.

Peleg, M. (1988), An Empirical Model for the Description of Moisture Sorption Curves. Journal of Food Science, 53, 1216-1217. https//doi.org/10.1111/j.1365-2621.1988.tb13565.x

Pineda-Gómez, P., Rosales-Rivera, A., \& Rodríguez-García, M. E. (2012). Modeling calcium and water intake in threshed corn grain during thermo-alkaline treatment, Journal of Food Engineering, 113(3), 434-441. https://doi.org/10.1016/j.jfoodeng.2012.06.026

Pinkaew, H., Wang, Y. J., \& Naivikul, O. (2017). Impact of pre-germination on amylopectin molecular structures, crystallinity, and thermal properties of pre-germinated brown rice starches. Journal of Cereal Science, 73, 151-157. https://doi.org/10.1016/j.jcs.2016.12.013

Pontes, B. R. B. (2012). Preparação e Caracterização de Termoplásticos a partir de amido de arroz. Dissertação apresentada ao Instituto de Química de São Carlos, da Universidade de São Paulo, São Carlos, 2012.

Prakash, O., Rachelle, W., Benu, A., \& Peter, T. (2014). Parboiled rice: Understanding from a materials science approach. Journal of Food Engineering, 124, 173-183. https://doi.org/10.1016/j.jfoodeng.2013.09.010. 
Prakash, O., Rachelle, W., Benu, A., \& Peter, T. (2016). Colour change in rice during hydration: Effect of hull and bran layers. Journal of Food Engineering, 173, 49-58, https://doi.org/10.1016/j.jfoodeng.2015.10.036

Pramiu, P. V., Rizzi, R. L., do Prado, N. V., Coelho, S. R. M., \& Bassinello, P. Z. (2015). Numerical modeling of chickpea (Cicer arietinum) hydration: The effects of temperature and low pressure, (2015). Journal of Food Engineering, 165, 112-123. https://doi.org/10.1016/j.jfoodeng.2015.05.020

Quicazán, M. C., Caicedo, L. A., \& Cuenca, M. (2012). Applying Peleg's equation to modelling the kinetics of solid hydration and migration during soybean soaking. Ingeniería $e$ Investigación, 32(3),

53-57. http://www.scielo.org.co/scielo.php?script=sci_arttext\&pid=S012056092012000300011\&ln= en\&tlng=en

Resende, O., \& Corrêa, P. C. (2007). Modelagem matemática do processo de hidratação de semente de feijão. Acta Scientiarum. Agronomy, 29(3), 373-378, https://www.redalyc.org/articulo.oa?id=3030/303026574012

Rosana, C., Shanise, L. M. El H., Vania, Z. P., Josiane, B., Luiz, C. G., Elessandra, da R. Z., \& Alvaro, R. G. D. (2015). Acetylation of rice starch in an aqueous medium for use in food, (2015). LWT-Food Science and Technology, 62(2), 1076-1082. https://doi.org/10.1016/j.lwt.2015.01.053

Rosana, C., Vânia, Z. P., Shanise, L. M. El H., Bárbara, B., Luciana, P., Danilo. D. C., ... Alvaro, R. G. D. (2017). Acetylated rice starches films with different levels of amylose: Mechanical, water vapor barrier, thermal, and biodegradability properties, Food Chemistry, 221, 1614-1620, https://doi.org/10.1016/j.foodchem.2016.10.129

Rulland, W. (1974). International tables of x ray crystallography. Birmingham: kinoch Press, 1974. 85p.

Shafaei, S. M., Masoumi, A. A., \& Roshan, H. (2014). Analysis of water absorption of bean and chickpea during soaking using Peleg model, 2016. Journal of the Saudi Society of Agricultural Sciences, 15(2), 135-144, https://doi.org/10.1016/j.jssas.2014.08.003.

Sichaya, S., \& Shi, Y. C. (2016). Changes of starch during parboiling of rice kernels, 2016, Journal of Cereal Science, 69, 238-244. https://doi.org/10.1016/j.jcs.2016.03.015

Sousa, F. C, Martins, J. J. A, Rocha, A. P. T., Gomes, J. P, Pessoa, T., \& Martins, J. N. (2015). Predição de modelos sobre a cinética de secagem de folhas de Ziziphus joazeiro Mart. Revista brasileira de plantas medicinais, 17(2), 195-200. https://doi.org/10.1590/1983-084X/12_071

Souza, R. C. R., \& Andrade, C. T. (2000). Investigação dos processos de gelatinização e extrusão de amido de milho. Polímeros, 10(1), 24-30. https://doi.org/10.1590/S0104-14282000000100006

Takuma, G., Fumihiko, T., Daisuke, H., \& Toshitaka, U. (2011). Incidence of open crack 


\section{Macrothink}

formation in short-grain polished rice during soaking in water at different temperatures, Journal of Food Engineering, 103(4), 457-463, ISSN 0260-8774. https://doi.org/10.1016/j.jfoodeng.2010.09.022

Thaisa, C. V. B., Luiz, M. de M. J., \& Regina, M. M. J. (2017). Modeling the hydration step of the rice (Oryza sativa) parboiling process. (2018). Journal of Food Engineering, 216, 81-89. https://doi.org/10.1016/j.jfoodeng.2017.07.020

Thaisa, C. V. B., Luiz, M. de M. J., \& Regina, M. M. J. (2017). Mathematical modeling of paddy (Oryza sativa) hydration in different thermal conditions assisted by Raman spectroscopy, (2018), Journal of Cereal Science, 79, 390-398, ISSN 0733-5210. https://doi.org/10.1016/j.jcs.2017.11.019.

Wang, S., Wang, Q., Hu, Y. M., Xu, S. N., He, Z. X., \& Ji, H. S. (2015). Study on the synergistic co-pyrolysis behaviors of mixed rice husk and two types of seaweed by a combined TG-FTIR technique, Journal of Analytical and Applied Pyrolysis, 114, 109-118, https://doi.org/10.1016/j.jaap.2015.05.008

Wu, Y., Chen, Z. X., Li, X. Z., \& Wang, Z. J. (2009). Retrogradation properties of high amylose rice flour and rice starch by physical modification, (2010). LWT - Food Science and Technology, 43(3), 492-497. https://doi.org/10.1016/j.lwt.2009.09.017

\section{Copyright Disclaimer}

Copyright for this article is retained by the author(s), with first publication rights granted to the journal.

This is an open-access article distributed under the terms and conditions of the Creative Commons Attribution license (http://creativecommons.org/licenses/by/4.0/). 